\title{
Tourism Masterplan of Senduro District in Lumajang Regency
}

\author{
Abigail Gracia Balthazar \\ Tourism Destination Management Program \\ Bandung Institute of Tourism \\ Bandung, Indonesia \\ balthazarabigail@gmail.com \\ Arini Ulfa Rahmawati \\ Tourism Destination Management Program \\ Bandung Institute of Tourism \\ Bandung, Indonesia \\ rahmawati.arini2@gmail.com \\ Farhan Alfarizi \\ Tourism Destination Management Program \\ Bandung Institute of Tourism \\ Bandung, Indonesia \\ farhanalfarizi20@gmail.com \\ Julia Tri Palupi \\ Tourism Destination Management Program \\ Bandung Institute of Tourism \\ Bandung, Indonesia \\ juliatripalupi@gmail.com
}

\author{
Muchammad Rizky \\ Tourism Destination Management Program \\ Bandung Institute of Tourism \\ Bandung, Indonesia \\ rizkymuchammad0@gmail.com \\ Yudha Permana \\ Tourism Destination Management Program \\ Bandung Institute of Tourism \\ Bandung, Indonesia \\ Yudha77permana@gmail.com \\ Willy Palenteng \\ Tourism Destination Management Program \\ Bandung Institute of Tourism \\ Bandung, Indonesia \\ palentengwilly@yahoo.com \\ Lanang Muhammad Gayuh Nugraha \\ Tourism Destination Management Program \\ Bandung Institute of Tourism \\ Bandung, Indonesia \\ mugiwaralanang@gmail.com
}

\begin{abstract}
Senduro District is one of the potential destinations for tourism in Indonesia, located in Lumajang Regency, East Java. As a destination that stores various potential attractions, especially for nature tourism, this district requires a master plan to guide the development, marketing, and various other aspects. This district also has an area that is included in the protected area of Bromo Tengger Semeru National Park and is also included in disaster-prone areas, especially the eruption of Mount Bromo and Semeru.
\end{abstract}

Keywords—nature tourism; master plan; regional planning; tourism; resort

\section{INTRODUCTION}

One of the districts in Lumajang Regency in East Java, named Senduro District, has lots of potential attractions, one of the favorite attraction is the peak of B29, the next potential view point of Mount Bromo and Semeru after Pananjakan 1 and 2 in Probolinggo Regency that start to be too crowded for tourists. Besides, this district has been dominated by 7 more natural attractions from overall 12 attractions so this region is potentially planned for nature tourism. This district also planned for tourism and agriculture, protected forest area, and also geological protected area of volcanic eruption (Regional
Spatial Plan of Lumajang Regency 2012 - 2032). In the LandUse Plan, this district is called a potential tourist destination but located in the protected area. The District of Senduro must have a referral development to minimize the spontaneous development of tourism. Most of the locations of the attractions are included in the area of Bromo Tengger Semeru National Park, resulting in the requirement of cooperation among relevant agencies for the development. Based from the observation, this area still has not the tourism master plan. From UN-WTO, master plan means to formulate a long-term development framework for tourism (10-20 years) with emphasis on policy and strategy, planning, institutional strengthening, legislation and regulation, product development and diversification, marketing and promotion, tourism infrastructure and superstructure, economic impact of tourism and tourism investment, human resource development, and socio-cultural and environmental impacts of tourism. Senduro District needs a resort master plan for the development that use the concept of nature tourism by considering the potential attractions, regional planning concept as the destination, and destination products for invent the potentials. 


\section{A. Nature Tourism}

Nature tourism is the broad term used to describe tourism that having contact with the natural environment. It can refer to both the flora and fauna of an area and can be associated with environments modified by man (Richardson \& Flucker, 2004: 72). Nature tourism as all tourism directly dependent on the use of natural resources in a relatively undeveloped state, including scenery, topography, water features, vegetation and wildlife (Newsome, Moore and Dowling (2002) in Espinoza confirmed by Ceballos-Lascuráin, 1996). Natural attraction as the attraction that is based on features $n$ the natural environment (Inskeep 1991: 77). The classifications of Nature Tourism are adopted from Srawbrooke (2005: 50) and Inskeep (1991: 77) classified to:

1) Natural resources: water, climate air

2) Natural environment: mountain areas, rivers and lakes, natural woodlands

3) The farmed environment: intensive crop rearing, traditional mixed farming, monoculture cash-crops, nomads in livestock rising, wood farm

4) Wildlife: flora, birds, land-base of mammals and reptiles

5) The built environment: individual buildings and structures, villages and townscapes, transportation infrastructure, roads and airports

6) The special environment

7) Parks and conservation areas

\section{B. Regional Planning Concept}

Basically a tourist destination is a geographical area that has an attraction for tourists (Morrison, 2013: 4). The geographical situation of a destination should be known clearly to know the basic needs required by the specific destinations. The aspects that should be known are the location, natural environment, history influence, socio cultural and economic pattern, land use, housing, and land ownership, and environment quality (Inskeep, 1991: 55-66). Regional plan divide the destination in to five regions: circulation, gateway, community, linkage, and attractions (Gunn 1994:225).

\section{Destination Product Concept}

The tourist products considered as an amalgam of three main components. There are attraction, facilities at the destination and accessibility of the destination (Middleton, 2001: 122). We are also searching for price aspect and also image so this destination can be competitive to be visited by tourists in the future.

\section{Location}

The research location is in Senduro District, Lumajang Regency. This is because numbers of favorite tourist attractions like the peak of B29, Hindu Temple of Mandhara Giri Semeru Agung, and Pani Lake located in Senduro District and also with other surrounding attractions.

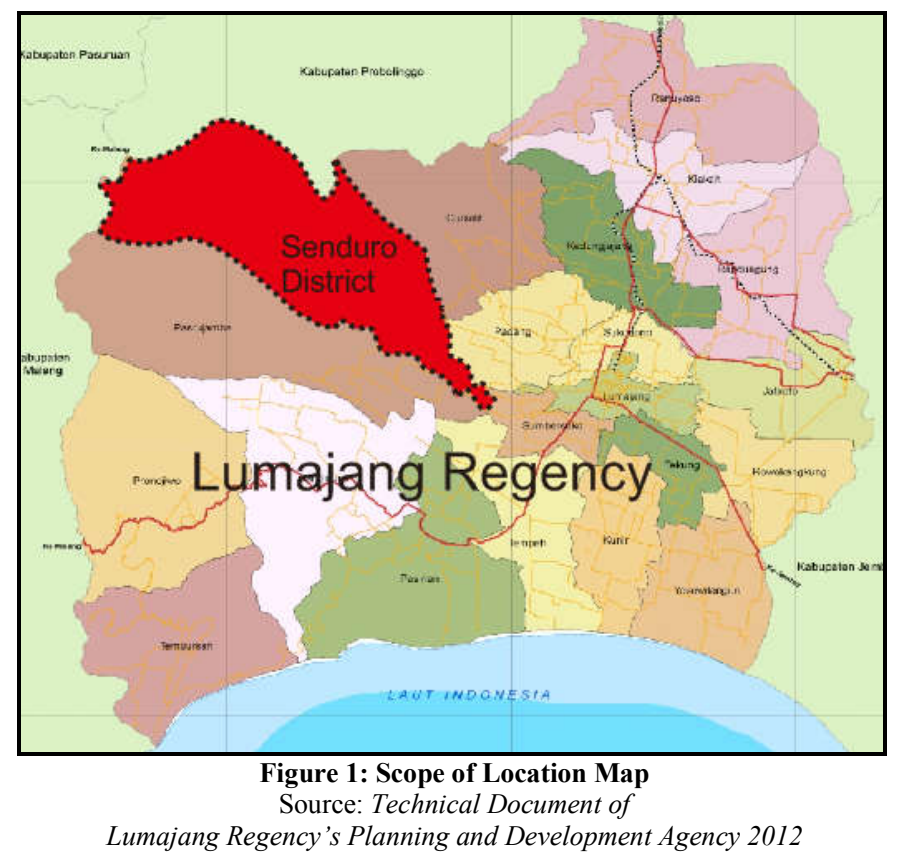

\section{RESEARCH METHOD}

In this study, research method use is descriptive method with qualitative approach. The data gathered by observation, interview, literature study, and also electronic media. Researchers also use Global Positioning System (GPS) digital camera and recorder for tools. The population is the entire tourism stakeholder in Senduro District. Similarly, snowball sampling technique used by specifying the key informants to Department of Culture and Tourism, Department of Planning and Development, Department of Transportation, Department of Public Works, Department of Livestock, Department of Environment, Disaster Management Agency, Secretary of Senduro District, Head of Argosari Village, Head of Senduro Village, Chairman of Local Working Group in the Subdistrict of Senduro, Tourism Awareness Group in Senduro, Local Communities, and also Tourists. The unit of analysis divided into three aspects, there are:

1) Actual and potential attractions in Senduro District,

2) Physical aspect including of geography, topography, climate, geology, hydrology, specific resources, flora and fauna, space pattern, and environmental conditions,

3) Non-physical aspect including of policy, socio-cultural conditions, socio-economical conditions, and also tourists as a market.

The procedure of data processing is done through the process of examining the data, data reduction, data presentation and data verification (conclusion). Descriptive data were analyzed qualitatively using SWOT analysis. 


\begin{tabular}{|c|c|c|}
\hline EFAS & STRENGIHS (S) & WEAKNESSES (W) \\
\hline $\begin{array}{l}\text { OPPORTENIT IFS } \\
\text { (O) }\end{array}$ & $\begin{array}{l}\text { STRATEGI } \\
\text { SO }\end{array}$ & $\begin{array}{l}\text { STRATE GI } \\
\text { WO }\end{array}$ \\
\hline $\begin{array}{l}\text { TRE ATHS } \\
\text { (I) }\end{array}$ & $\begin{array}{l}\text { STRATEGI } \\
\text { ST }\end{array}$ & $\begin{array}{l}\text { STRATE GI } \\
\text { WT }\end{array}$ \\
\hline
\end{tabular}

Figure 2: SWOT Matrix

Source: Freddy Rangkuti, 2006

\section{FINDINGS AND DISCUSSION}

Here is the description of the findings after being analyzed in the research

\section{A. Internal Factors}

There are numbers of Strength here in this District. Senduro District located in the border region, so there are several options as the entrance. There are kinds of land configurations from mountains, valleys, hills, and plateaus. Cool temperatures at Senduro become more valuing nature tourism, furthermore, tourists love it. This area has a good view with the good visibility that dominates by green fields in some of the access roads leading to tourist attractions. Senduro District has a clean environment marked by not seen any garbage in the area in general.

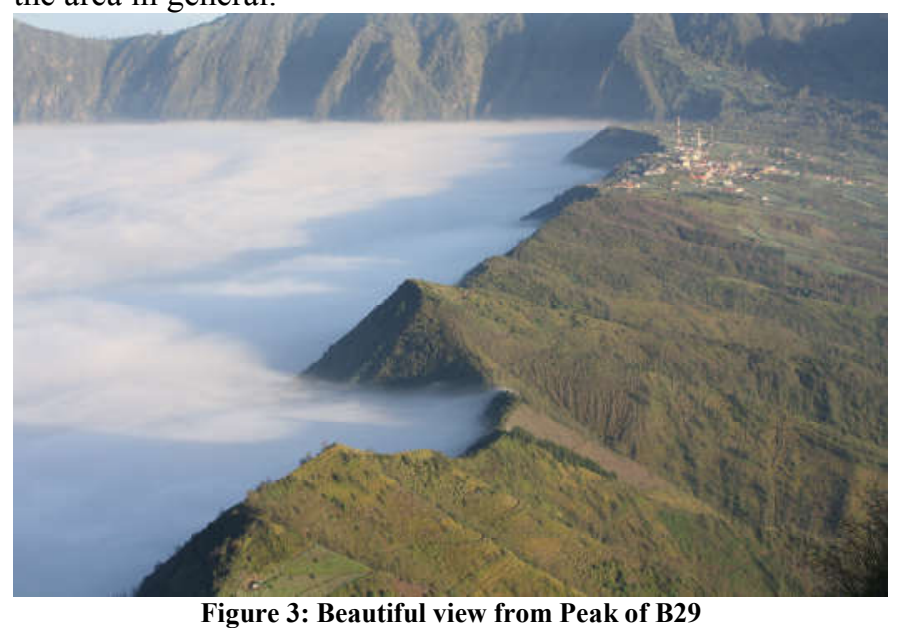
Source: Documentation

The existence of the Bukit 29 (Hill 29), here tourists can experience as a climber, although without having to climb to the mountain because of the availability of public transportation (motorcycle) for visitors to Bukit 29. The existence of the temple of Mandhara Giri Semeru Agung has great historical value, especially for people with Hindu belief. Aglonema plant is a potential attraction in this destination along the way to the attraction. Senduro District also has a good quality of access road to the entrance of tourist attractions.
This district also have the weaknesses. At a time, high rainfall may affect the condition of the road access to the attraction gets wet and slippery. The configuration of the land in Senduro District included in disaster-prone area. Some locations in district of Senduro for example, in the village of Argosari are easily avalanched since many redirects functions of land. At the time, the rainy season can affect the level of the visit of tourists coming in Senduro, because tourists cannot visit some of the attractions when the rain came. The distance between attractions in this district is relatively far. Also the coordination between stakeholders and related tourism sectors are inadequate.

There is the lack of health facilities which are relatively far from each tourist attractions and lack of security facilities with a total of only 1 in Senduro. Still lack of interpretation facilities includes brochures, info boards, signs and interpreters in any attractions, lack of facilities such as the transportation rental, and numbers of accommodation facilities. There is also numbers of attractions that not have the management to organize the sites development.

\section{B. External Factor}

There are many Opportunities in Senduro District. This district includes the territory of KSPN (National Tourism Strategic Area) so that this district has an active role as a strategic investment location and driving force of tourism development for the surrounding area. East Java Province tourism development plan is accordance with the actual condition of Senduro that planned for natural and cultural tourism. Regency Tourism development plan meets the rules of sustainable tourism development given that the tourist attraction that is dominated by natural attractions and some of them are located in protected areas (Bromo Tengger Semeru National Park). District of Senduro's position is set for tourism destination so that the construction of its facilities will meet the needs for travelers. The tourism sector is one of the priority sectors of Lumajang Regency's development. People of Senduro also keep the religious harmony. The tourism sector is giving the second largest GDP for Lumajang after sector of the economy, so that the tourism sector can boost the local economy. The agricultural sector is producing the biggest contribution in the District Senduro potential as a supplier of tourism activities and its land can be used as a tourist activity that is agro tourism. Also the advance technology like social media can be used as a media campaign.

There are also the threats that this district has. Rule utilization and conservation of the national park area has not been fully implemented in Senduro, so that the negative impact cannot be anticipated from tourism activities. Characteristics of rural communities tend to be jealous of the success of an individual or groups that could trigger social conflict. 


\begin{tabular}{|c|c|c|}
\hline IFAS & Strengths (S) & Weaknesses (W) \\
\hline $\begin{array}{l}\text { Oppor- } \\
\text { tunities } \\
\text { (O) }\end{array}$ & $\begin{array}{l}\text { Strategi S-O } \\
\text { 1. Utilize the agricultural } \\
\text { sector in the District } \\
\text { Senduro as agro tourism. } \\
\text { 2. Develop the district's } \\
\text { nature as a major tourist } \\
\text { attraction. } \\
\text { 3. Making } \\
\text { tourism as a supporting } \\
\text { attraction. }\end{array}$ & $\begin{array}{l}\text { Strategi W-O } \\
\text { 1. Making the coordination } \\
\text { with related stakeholders. } \\
\text { 2. Establish the management } \\
\text { organization in every tourist } \\
\text { attractions } \\
\text { 3. Create a system to provide } \\
\text { information that is easily } \\
\text { accessible. } \\
\text { 4. Increase the interpretation } \\
\text { techniques in tourism area }\end{array}$ \\
\hline $\begin{array}{c}\text { Threats } \\
\text { (T) }\end{array}$ & $\begin{array}{l}\text { Strategi S-T } \\
\text { 1. Establish zoning and } \\
\text { clustering in the District } \\
\text { Tourism Regions Senduro. } \\
\text { 2. Supervise or control } \\
\text { tourist traffic at every } \\
\text { entrance. } \\
\text { 3. Making } \\
\text { coordination with related } \\
\text { stakeholders. } \\
\text { 4. Provide counseling to } \\
\text { villagers about how to run } \\
\text { the right tourism } \\
\text { industries }\end{array}$ & 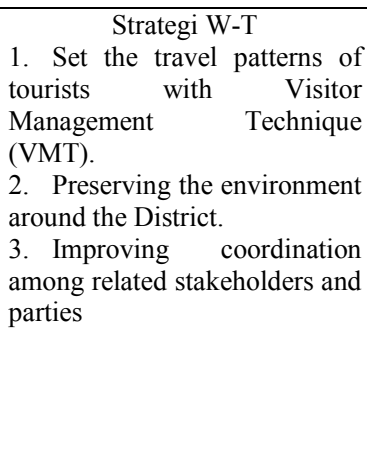 \\
\hline
\end{tabular}

Table 1: SWOT Matrix of Senduro District

\section{CONCLUSSION AND SUGGESTION}

Careful planning is required to determine the optimum type and level of tourism that will not result in environmental degradation and to utilize tourism as a means to achieve environmental conservation objectives (Inskeep, 1991). Senduro is one of the District in Lumajang Regency in which has a similar appeal with the Hill of Bukit pananjakan (Mount Bromo), that is B-29 in the village of Argosari, a very potential destination to be developed as a tourist attraction. In addition, there were a variety of natural and cultural attractions that will be damaged if they are visited by mass tourist, without a careful planning. Senduro District stated for six main strategies, those are:

\section{A. Zoning Strategies}

Zoning in the area of Senduro District applied to divide the area of the district based on the usability with the usefulness of the land. Zoning also serves to keep an eye on the development of tourism industry in Senduro in order not to damage the existing environmental conditions. The zoning is as follows:

1) Wilderness zone or Non intervention zone: the zone that include the area of Bromo Tengger Semeru National Parks based on RTRW of Lumajang Regency (red).

2) Buffer Zone: development of the region as the border area before entering the area of the Wilderness zone(yellow).
3) Intensive Use Zone: the development of the region as an integrated region and urban area in Senduro District (green).

4) Intensive Use Enclaves or Corridor Zone: development of the region to prepare for accommodating tourists in large quantities within a certain time (orange dot).

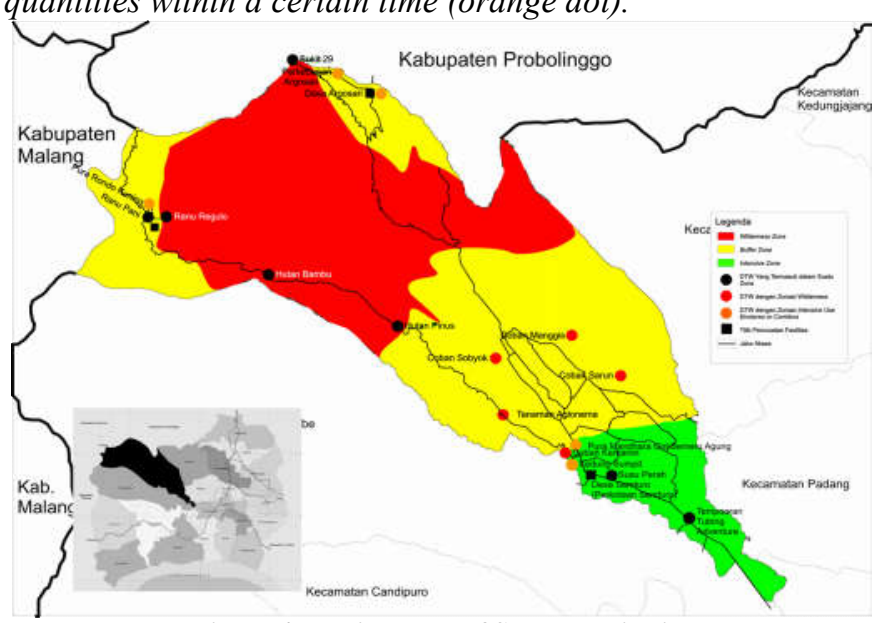

Figure 4: Zoning Map of Senduro District

\section{B. Clustering Strategies}

Clustering used to split the existing tourism attraction in Senduro District that suit the characters in the activities that can be done on existing tourism attraction. There are four clusters that will be applied

1) Recreation Cluster: the development of Water Related Activities such as tubing and swimming, the development of Heritage tourism as a tourist attraction, supporting the development of agrotourism activity with goats and cows dairy mils, the management of the Nyepi holiday celebrations in the form of a parade of Ogoh-Ogoh as one of the annual events, and the development of souvenirs handicrafts production centre.

2) Education Cluster: the Development Education activity of stargazing, recreation activities such as camping, sightseeing, wildlife watching, and event the taking of holy water as a cultural attraction.

3) Adventure Cluster: development of the swimming hole, as the activity of water adventure in the bottom of the waterfall, trekking along the path and developing the activity toward a variety of waterfalls attraction.

4) Argosari Rural Tourism Cluster: developing educational activity includes studying the Tenggerese culture of rural life, perform daily activities, and studying the Tenggerese ceremony, developing farming activity, camping, and trekking activities, develop the stargazing activity, also Nyepi Celebration of Tenggerese people as the annual event

\section{Do the coordination between stakeholders}

1) Creates interdependence and maintaining balance relationship between Government partnership with private parties and community. 


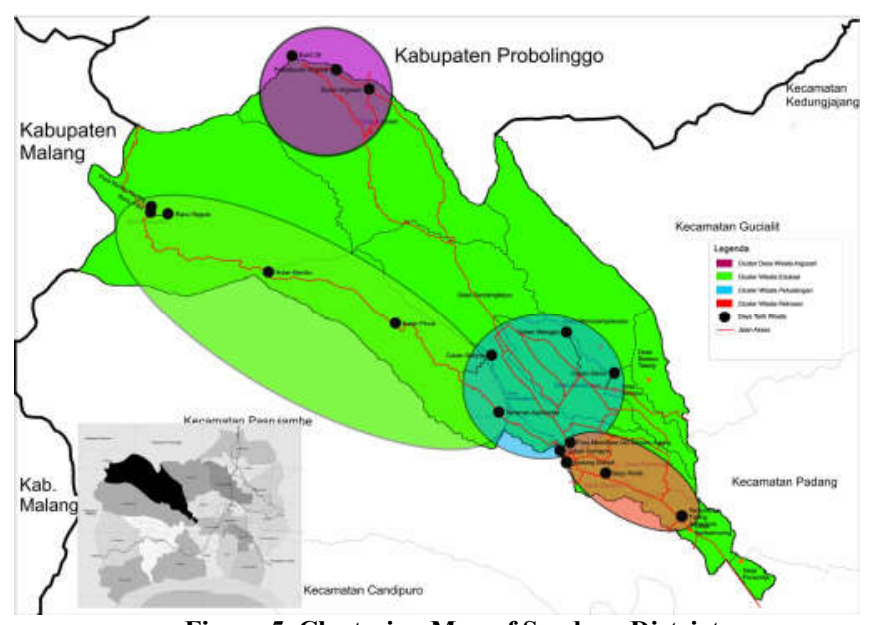

Figure 5. Clustering Map of Senduro District Source: Documentation

2) Do with the disaster-prone mitigation guidance regarding the potential and impact of disasters that occur along with providing evacuation.

3) Improving cooperation regarding the quality of the community in the field of tourism, such as providing training to become tour guides, provide training on how to make souvenirs and tourism facility rental as homestay

4) Organising cooperation regarding rendering land use when the existence of the land use for tourism activities

5) Establish cooperation for developing the agro tourism in the tourist area of Kecamatan Senduro with a view of the suitability of the time travellers with harvest season.

6) Enhance cooperation regarding proper hygiene is in district Senduro like garbage hauling schedule and conduct the program the bank trash every village is located in district Senduro.

7) Enhance cooperation regarding replanting of land (reforestation) in subdistrict of Senduro.

8) Conduct cooperation on the utilization of dairy goat farm and dairy cows as a tourist attraction, including the cooperation in providing recommendations for the best time to visit.

9) Do the cooperation regarding the number of frequency mode of public transportation in district Senduro.

\section{Managing Visitor Management Technique (VMT) In The}

Tourist Area of Senduro District.

VMT can help maintain environmental conditions in Senduro District in order not to receive excessive negative impacts. The directions of the development of Visitor management technique (VMT) tourist area in Senduro District are as follows:

1) Limitingamount of visitors with the distribution of travellers to various tourist attractions in Senduro District.

2) Development of the entrance (gateway) depends from the condition of tourist facilities and infrastructure are adequate in Senduro District.
3) Development of tourism packages in Senduro Subdistrict, such as educational tour packages or tour packages to adventure tourism, rural tourism package

\section{E. Managing Interpretation in the TouristAarea of Senduro District.}

1) Interpreters who came from local communities

2) Making some of indirect interpretation which include slides, videos, films, series of pictures.

3) Development of the signpost towards to every tourist attraction in Senduro

4) Development Board information about flora

5) Provide Specific interpreters services concerning historical tourist attraction

6) Information about things that should or shouldn't do in every tourist recreation.

\section{F. Conduct environmental preservation around the tourist} area of Senduro district.

1) Reforestation, namely in the form of replanting crops especially in areas that have been deforested hills.

2) Making sengkedan (terracing) for the land that prone to erosion.

3) Prohibit disposal household waste in order not to flow directly into the river.

4) Provision of Trash.

5) Enforce Water-taking Permits (SIPA) mainly to industrial activity that requires water.

6) Industrial waste neutralization before being dumped into a river. Thus, any factory or industrial waste processing units required to have known the term wastewater treatment Installations (IPAL).

\section{References}

A. Books

[1] Arikunto, S. (2010). Prosedur Penelitian: Suatu Pendekatan Praktik (Edisi Revisi). Jakarta: Rineka Cipta

[2] Arikunto, Suharsimi. (2006). Prosedur Penelitian Suatu Pendekatan Praktik. Jakarta: Rineka Cipta

[3] Badan Perencanaan dan Pembangunan Daerah. 2011-2031. Rencana Detail Tata Ruang Kota Kecamatan Senduro. Lumajang

[4] Badan Pusat Statistik. 2014. Kabupaten Lumajang dalam Angka 2014. BPS Lumajang.

[5] Badan Pusat Statistik. 2014. Kecamatan Senduro dalam Angka 2014. BPS Senduro.

[6] Basrow dan Swandi. (2008) Memahami Penelitian Kualitatif. Jakarta: PT Rineka Cipta

[7] Basuki, Sulistyo. (2010). Metode Penelitian. Jakarta: Penaku

[8] Bell et al (2007) Outdoor Recreation and Nature Tourism: A European Perspective. [PDF] UK: Living Reviews.

[9] Da Cunha, Sieglinde Kindl, 2005. Tourism Cluster Competitiveness and Sustanability: Proposal for a Systemic Model to Measure the Impact of Tourism on Local Development. Curitiba: Universidade Federal do Parana. 
[10] Dinas Kebudayaan dan Pariwisata Kabupaten Lumajang. 2016-2025. Rencana Tata Ruang Wilayah. Lumajang.

[11] Dinas Kehutanan Kabupaten Lumajang. 2013. Kehutanan Dalam Angka. Lumajang.

[12] Drumm \& Moore (2005). An Introduction to Ecotourism Planning. Second Edition.Volume 1. [PDF]Arlington, Virginia, USA

[13] Eagles, Paul F.J., et. al. 2002. Sustainable Tourism in Protected Areas: Guidelines for Planning and Management. Cambridge: IUCN.

[14] Faizi Zahari, 2012. Mengapa Perencanaan Pariwisata itu Penting dalam The Planners ePortfolio. Halam 4. 2012.

[15] Gunn. Clare. A (1994) Tourism Planning Basic Concepts Case. Third Edition. United States Of America : Taylor \& Francis

[16] H. B. Sutopo. (2006). Metodologi Penelitian Kualitatif: Dasar Teori dan Terapannya Dalam Penelitian. Surakarta: Universitas Sebelas Maret

[17] Inskeep (1991). Tourism Planning An Integrated and Sustainable Development Approach. New York :Van Nostrand Reinhold

[18] Kuntowijoyo, 1980. "Social Change in Agrarian Society : Madura 1850 - 1940". Disertation. New York : Columbia University.

[19] Marsongko, E.P (2001). Elemen - elemen Kebudayaan dan Pariwisata. Bandung.

[20] Middleton, V. \& Jeckie. R. C (2001). Marketing in Travel and Tourism. Third Edition. "London: Butterworth Heinemann.

[21] Mitra Iranti Utami (2011). Pesona Masyarakat Tengger, Surabaya.

[22] Moleong, L. J. (2012). Metodologi Penelitian Kualitatif Edisi Revisi. Bandung: PT Remaja Rodakarya

[23] Morrison. A.M (2013) Marketing and Managing Tourism Destination. London \& New York : Routledge Taylor \& Francis.

[24] Muhammad Nazir, 1988, Metode Penelitian, Ghalia Indonesia, Jakarta.

[25] Newsome, D., Moore, S.A. and Dowling, R. (2002) Natural Area Tourism: Ecology, Impacts and Management. Clevedon, England: Channel View Publications.

[26] Peraturan Daerah Provinsi Daerah. 1998. PP Nomor 50 Tahun 2011 tentang Rencana Induk Pengembangan Pariwisata Nasional. 2014. Provinsi Jawa Timur.

[27] Peraturan Daerah Provinsi Daerah. 1998. Rencana Induk Pengembangan Pariwisata. 2014. Provinsi Jawa Timur.

[28] Pride, William. M dan O. C. Ferrel, 1995. Pemasaran Teori dan Praktek Sehari-hari. Jakarta : Penerbit Binarupa Aksara.

[29] Rangkuti, Freddy. (2006). Analisis SWOT Teknik Membedah Kasus Bisnis. PT. Gramedia Pustaka Utama, Jakarta.
[30] Rich, Doroty, 2012. Concept of Zoning Management In Protected Areas. Eldoret: Moi University

[31] Richardson \& Flucker (2004) Understanding and Managing Tourism. Australia : Pearson Education Australia

[32] Rogers, E. 1969. Modernization Among Peasants: The impact Of Communication. New York: Hold Rinehart Dan Winston.

[33] Sugiono (2013). Metode Penelitian Pendidikan (Pendekatan Kuantitatif, Kualitatif, dan R\&D). Bandung: Alfabeta

[34] Sugiyono. 2009. Metode Penelitian Kuantitatif Kualitatif dan R\&B. Bandung: Alfabeta.

[35] Sugiyono. 2012. Metode Penelitian Kuantitatif Kualitatif dan R\&B. Bandung: Alfabeta.

[36] Suprayogo, I. \& Tobroni. (2001). Metodologi penelitian SosialAgama.Utama, Jakarta.

[37] Susanto, Rachman. 2005. Dasar-Dasar Ilmu Tanah Konsep dan Kenyataan. Kanisius. Jakarta.

[38] Tourism New South Wales. Tanpa Tahun. Defining Nature Tourism: Meaning, Value, and Boundaries.[PDF] New South Wales: Tourism NSW.

[39] UNWTO. 2014. UNWTO Tourism Highlight 2014 Edition. UNWTO.

[40] Yoeti, O.A. (1996). Pengantar Ilmu Pariwisata. Bandung: Angkasa

B. Website

[41] Backpacker. (TT). Tersedia : www.backpackerindonesia.com, [1 Maret 2015]

[42] Heni, P. (2014). Budaya Suku Tengger. Tersedia : http:atauataukusukageo.blogspot.comatau2014atau09ataupesonabudaya-suku-tengger-di-desa.html, [ 01 Maret 2015]

[43] Lumajang. (TT). Tersedia : http:atauataulumajangkab.go.idatau [28 February 2015]

[44] Lumajang. (TT). Tersedia : http:atauataulumajangkab.go.idatau, [28 February 2015]

[45] pariwisatalumajang.blogspot.comataupataupariwisata-lumajang-html

[46] Senduro.

Tersedia:http:atauatauinovasipeternakan.blogspot.comatau2014atau05at auprofil- kecamatansenduro.html, [28 February 2015]

[47] Wikipedia. (TT). Tersedia http:atauatauid.wikipedia.orgatauwikiatauKabupaten_Lumajang. $\quad[18$ February 2015]

[48] Wikipedia. (TT).Tersedia http:atauatauid.wikipedia.orgatauwikiatauKabupaten Lumajang. [28 February 